\title{
A Study of the Underpotential Deposition of Lead on Gold by
}

\section{UV-Visible Differential Reflectance Spectroscopy}

\author{
Artur J. Motheo $^{a}{ }^{*}$, Ernesto R. Gonzalez ${ }^{a}$, Germano Tremilliosi-Filho $^{a}$, \\ André Rakotondrainibe ${ }^{b}$,Jean-Michel Léger ${ }^{b}$, Bernard Beden ${ }^{b}$, \\ and Claude Lamy \\ ${ }^{a}$ Instituto de Química de São Carlos, Universidade de São Paulo, C.P. 780, \\ 13560-970 São Carlos - SP, Brazil \\ ${ }^{b}$ Laboratoire de Chimie 1, "Electrochimie et Interactions" URA CNRS 350 \\ Université de Poitiers, 40, Avenue du Recteur Pineau, 86022 Poitiers Cedex, France
}

Received: November 26, 1996

\begin{abstract}
A deposição, em regime de sub-tensão, de chumbo sobre ouro, foi estudada por voltametria cíclica e espectroscopia de reflectância diferencial no domínio UV-visível. Os experimentos foram realizados em forma comparativa empregando-se eletrodos de ouro policristalino e monocristalinos de orientações (111) e (210). Para as superfícies monocristalinas, os resultados de reflectância confirmam o significativo efeito da orientação cristalográfica durante a deposição e redissolução do chumbo sobre as diferentes superfícies de ouro estudadas. $\mathrm{O}$ trabalho mostra que a existência de diferentes tipos de estruturas para o chumbo adsorvido depende não só da distribuição atômica do substrato mas acima de tudo do potencial aplicado. Adicionalmente, é feita uma tentativa para explicar o comportamento do ouro policristalino com base nos resultados obtidos para os dois monocristais pesquisados.
\end{abstract}

The underpotential deposition of lead on gold has been studied by cyclic voltammetry and UV-visible differential reflectance spectroscopy. Comparative experiments were carried out with a polycrystalline gold electrode and two single-crystal gold electrodes with the orientations (111) and (210). For the single crystal surfaces, the reflectance results confirm the large effect of the crystallographic orientation on the deposition and redissolution of lead on gold surfaces. The existence of different types of structures for adsorbed lead, depending not only on the atomic distribution of the substrate but above all on the electrode potential, is demonstrated. An attempt is made to explain the behavior of polycrystalline gold on the basis of the results obtained for the two investigated gold single crystal faces.

Keywords: underpotential deposition, gold single crystals, spectroelectrochemistry, $U V$ visible differential reflectance spectroscopy

\section{Introduction}

Electrocatalytic processes are widely studied, firstly to understand better their reaction mechanisms, secondly to improve industrial applications. The reaction mechanisms can be studied by modifying the structure of the electrode surface in order to influence the adsorption of the different species involved in the electrocatalytic processes. One way of modifying a catalytic metallic surface is to deposit a second metal on it by a galvanostatic, potentiostatic or electroless procedure. Bulk metal deposition is preceded by the gradual build-up of a monolayer, or of a submonolayer, at potentials more positive than the reversible Nernst potential of the bulk deposition, in what is called underpotential deposition (upd). 
In upd the adsorbate-substrate interactions are stronger than the adsorbate-adsorbate ones. Obviously, foreign atoms influence the catalytic properties of the surface ${ }^{1}$. The thermodynamic, kinetic and structural aspects of the upd of lead on gold surfaces have been the subject of many studies $^{2-9}$ which have demonstrated the strong dependence of the adsorption behavior of lead on the crystallographic orientation of the gold substrate ${ }^{8,9}$. Additionally, it was observed that coadsorption phenomena are absent in the underpotential range and that lead upd on single crystal gold surfaces can be well described by the ideal monolayer model $^{5}$. The behavior of lead upd on a polycrystalline gold surface was similar to that on an $\mathrm{Au}(110)$ surface, which was explained by a possible predominance of (110) regions. It was confirmed that the deposition of lead on the (111) face and its removal were irreversible processes ${ }^{8}$.

The aim of the present work is to investigate the $\mathrm{Au} / \mathrm{Pb}$ system by using in situ UV-visible differential reflectance spectroscopy (UVDRS) in the wavelength range 350 to 750 $\mathrm{nm}$, during a cyclic voltammogram ${ }^{10-12}$. Polycrystalline $\mathrm{Au}$ and $\mathrm{Au}(\mathrm{h}, \mathrm{k}, \mathrm{l})$ electrodes in $10 \mathrm{mM} \mathrm{HClO}_{4}+1 \mathrm{mM}$ $\mathrm{Pb}\left(\mathrm{ClO}_{4}\right)_{2}$ solutions were studied. The gold single crystal faces chosen were the (111) and (210) planes in order to establish the spectroscopic behavior of two distinct single crystal orientations which exhibit a totally different electrochemical behavior ${ }^{8}$ and to compare them with polycrystalline gold.

\section{Experimental}

The electrochemical set-up consisted of a Wenking MP81 potentiostat, a X-Y recorder and a three-electrode, one-compartment cell. The polycrystalline gold electrode was prepared by melting a $99.95 \%$ gold wire in a graphite crucible with cylindrical internal shape. One of its faces (geometric area $0.166 \mathrm{~cm}^{2}$ ) was polished to a mirror finish. For the single crystals, all operations of crystal growth, orientation, cutting of individual faces and surface preparation were carried out at CNRS Meudon ${ }^{13}$. Just before their introduction into the cell, the electrodes were flame treated, cooled in ultra pure water and protected with a drop of water before their transfer to the electrochemical cell. The counter electrode was a gold wire which was also flame treated before immersion into the cell. All potentials were measured with respect to a commercial mercury-mercurous sulfate electrode (MSE) connected to the main compartment of the cell by a glass bridge elongated by a Luggin capillary.

The $10 \mathrm{mM} \mathrm{HClO}_{4}+1 \mathrm{mM} \mathrm{Pb}\left(\mathrm{ClO}_{4}\right)_{2}$ solutions were prepared with Suprapur grade acid and p.a. grade salt (both from Merck), and ultrapure water from a Millipore Milli Q system. All experiments were performed at room temperature.

The spectroelectrochemical technique used combines cyclic voltammetry and reflectance measurements, collect- ing spectra every few milliseconds and then calculating difference spectra between the averaged absorbance curves recorded at two different potentials. This procedure is indicated for systems in which the spectra at different potentials present only small changes. The potential dependence of the absorbance is a very powerful way to observe the formation of layers at electrode surfaces, as already shown for superficial oxides ${ }^{14}$. The optical equipment used consisted of a Harrick RSS-C rapid-scan spectrometer ${ }^{10}$. The light, from a quartz-halogen lamp, falls on a grating mounted on the mobile frame of a small galvanometer shaft and is split into a reference and a sample beam and collected by two identical Hamamatsu R955 photomultipliers. The resulting output signals are processed and averaged, and stored in a Nicolet 370 data acquisition system connected to a personal computer as $\Delta \mathrm{R} / \mathrm{R}$ (= $\left(R_{2}-R_{1}\right) / R_{1}$ where $R_{1}$ is the reference beam signal and $R_{2}$ is the reflected sample beam). The data treatment was made with a specific software, as described elsewhere ${ }^{10}$, which allows the calculation of the absorbance, $A$, as $-\log (\Delta R / R$ $+1)$ and the presentation of three-dimensional diagrams (absorbance-wavelength-potential). The electrochemical control of the system was made with the same potentiostat used in the voltammetric experiments and the cell used had a quartz cylindrical compartment with a glassy-carbon counter electrode of $c a .2 \mathrm{~cm}$ diameter and with a MSE reference electrode. The working electrodes were mounted in a syringe to facilitate their positioning into the cell and they were flame treated, as described above for the electrochemical experiments.

Two kinds of UVDRS experiments were carried out, one by taking spectra at fixed potentials at the values corresponding to the different upd peaks, and the other by taking spectra during a cyclic voltammogram $(\mathrm{CV})$ at $2 \mathrm{mV} \mathrm{s}^{-1}$. The wavelength range was from 350 to $750 \mathrm{~nm}$. Two two-dimensional presentations are possible: the dependence of the absorbance change, $\Delta \mathrm{A}$ (which is equal to the difference between the absorbance at a given potential and the absorbance at a reference potential) at a fixed wavelength (reflectogram) on the applied potential, and the dependence of $\mathrm{A}$ on the wavelength at a fixed potential (spectrum $)^{10}$. In this work the spectra are also displayed in three-dimensional diagrams as $(\Delta \mathrm{A}, \lambda, \mathrm{E})$.

\section{Results}

\section{Gold (111)}

The CV for lead upd on $\mathrm{Au}(111)$ shows five pairs of peaks, in agreement with that obtained by Hamelin ${ }^{8}$ using $\mathrm{HClO}_{4}+\mathrm{PbF}_{2}$ (Fig. 1). The cathodic peaks are labeled as follows: $\mathrm{A} 1=-0.36 ; \mathrm{A} 2=-0.40 ; \mathrm{A} 3=-0.52 ; \mathrm{A} 4=-0.59$; $\mathrm{A} 5=-0.65 \mathrm{~V} / \mathrm{MSE}$ and the anodic peaks as follows: $\mathrm{D} 1=$ $-0.205 ;$ D2 $=-0.29$; D3 = -0.36; D4 = -0.58; D5 = -0.62 V/MSE. According to literature ${ }^{9}$, peaks A1 and A2 could 


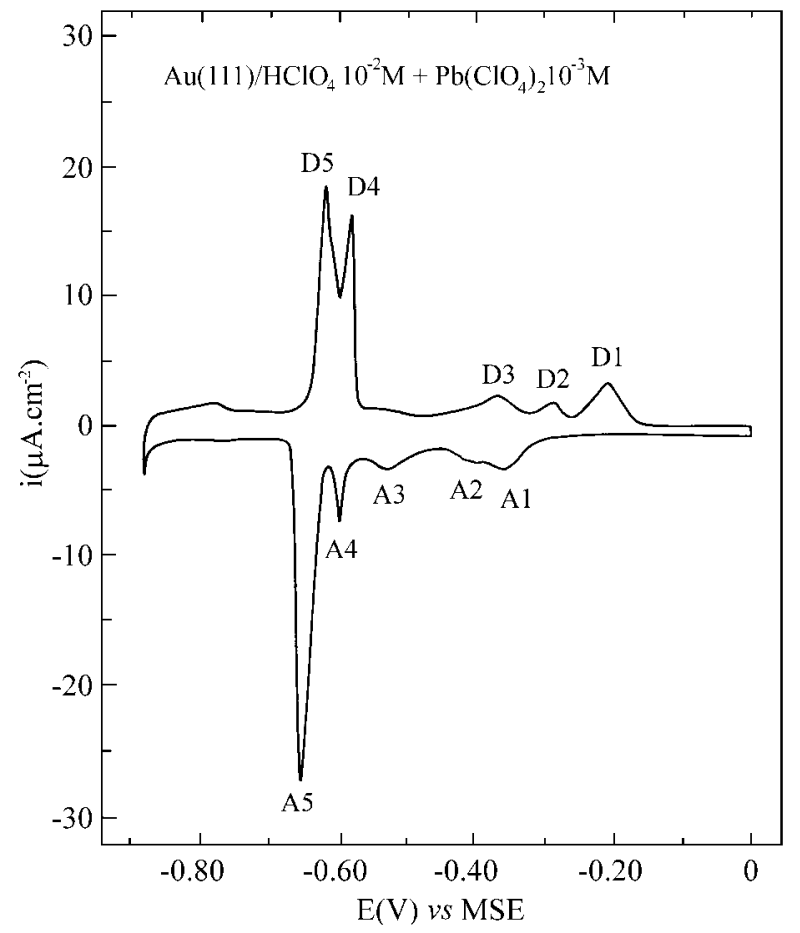

Figure 1. Cyclic voltammogram of $\mathrm{Au}(111)$ in $10 \mathrm{mM} \mathrm{HClO} 4+1 \mathrm{mM}$ $\mathrm{Pb}\left(\mathrm{ClO}_{4}\right) 2$ recorded at $10 \mathrm{mV} \mathrm{s}^{-1}$ in the potential range from 0 to $-0.88 \mathrm{~V}$ vs. MSE, temperature $\approx 25^{\circ} \mathrm{C}$.

be related either to a substrate modification by lead adsorption or to the adsorption of lead on the substrate surface defects. Peak A3 could be identified as corresponding to the $\mathrm{p}(1 \mathrm{x} 1)$ structure, peak A4 as displaying the $\mathrm{p}(\sqrt{3} \times \sqrt{3})$ $30^{\circ}$ geometry and peak A5 as corresponding to the $\mathrm{p}(\sqrt{28}$ $\mathrm{x} \sqrt{28}) 18^{\circ} 90^{\prime}$ structure. An adsorption isotherm has been used to describe lead upd on $\mathrm{Au}(111)^{5}$; at the potential of peak $\mathrm{A} 5$ over a range of just about $50 \mathrm{mV}$, the coverage increased dramatically from $\theta \approx 0.4$ to $\theta \approx 0.9$, which was interpreted as a transition between the $\mathrm{p}(\sqrt{3} \mathrm{x} \sqrt{3}) 30^{\circ}$ and the $\mathrm{p}(\sqrt{28} \times \sqrt{28}) 18^{\circ} 90^{\prime}$ structures of the lead submonolayer ${ }^{5}$.

Figure 2 shows UV-vis differential spectra for the $\mathrm{Au}(111) / \mathrm{Pb}$ interface at fixed potentials corresponding to the cathodic peaks (deposition of lead), with the spectrum at $0 \mathrm{~V} / \mathrm{MSE}$ as reference. In Fig. 3 the differential spectra, obtained during the negative (Fig. 3a) and positive (Fig. 3b) sweeps of the potential at a rate of $2 \mathrm{mV} \mathrm{s}^{-1}$ are shown. Comparing Figs. 2 and 3 one can see that the spectra taken at the fixed potential condition (Fig. 2) present a better definition of the bands than those taken during a potential sweep (Fig. 3). So, while in Fig. 2 there is a noticeable absorbance change at $\lambda>475 \mathrm{~nm}$ already at $\mathrm{E}=-0.52 \mathrm{~V}$ (peak A3), in Fig. 3 a similar change of the absorbance occurs only at $\mathrm{E} \leq-0.68 \mathrm{~V}$ (peak A5).

Comparing Figs. 3a and 3b, it can be observed that lead upd is fairly reversible. In the positive potential sweep, at

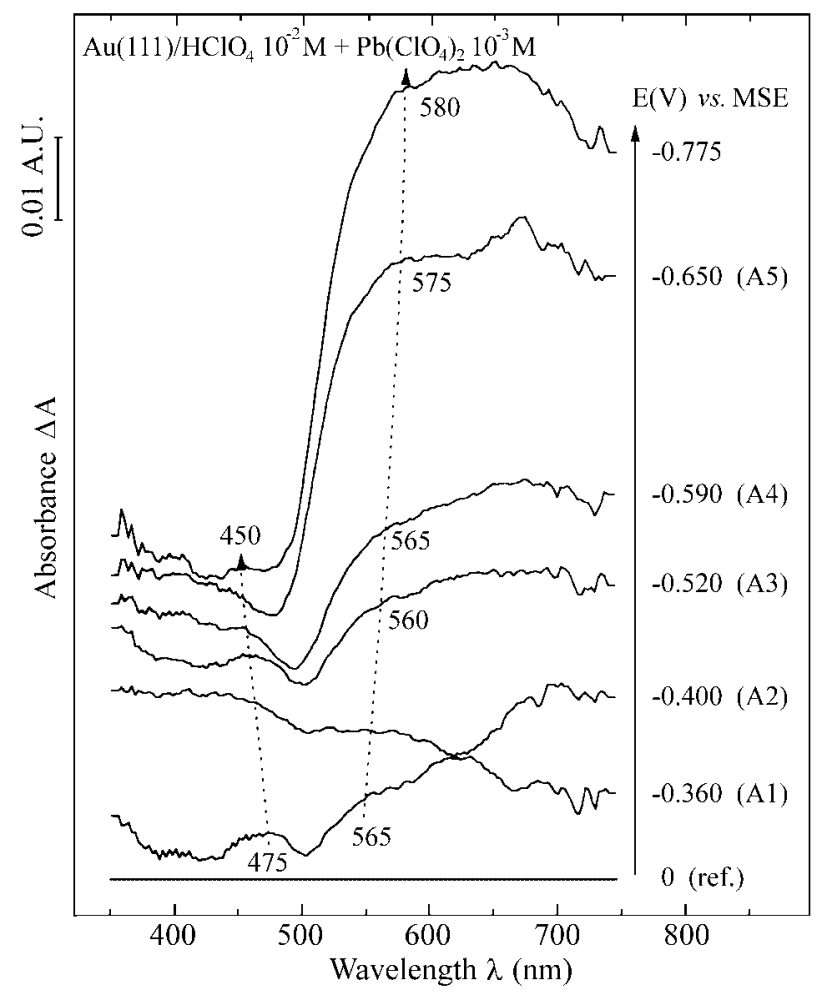

Figure 2. UV-visible differential reflectance spectra of $\mathrm{Au}(111) / 10 \mathrm{mM}$ $\mathrm{HClO}_{4}+1 \mathrm{mM} \mathrm{Pb}\left(\mathrm{ClO}_{4}\right)_{2}$ at the fixed potentials shown (reference spectrum taken at $0 \mathrm{~V} / \mathrm{MSE}$ ).

$\lambda>500 \mathrm{~nm}$ and $\mathrm{E}<-0.58 \mathrm{~V}$, the spectra obtained begin to show a better definition of the bands at 575 and $670 \mathrm{~nm}$. After plotting the spectra of Fig. 3 at different potentials, and rotating the xy plane by $\pi / 2$, we obtain the $3 \mathrm{D}$ spectra of $\mathrm{Au}(111) / \mathrm{Pb}$ displayed in Fig. 4. In the wavelength region between 350 and $525 \mathrm{~nm}$, the absorbance decreases during the deposition and increases during the dissolution of lead. On the contrary, above $525 \mathrm{~nm}$ the absorbance increases during the deposition and decreases during the dissolution of lead. It can be seen that after a potential cycle the spectra has changed slightly, since the final spectrum is not a horizontal line of zero absorbance.

At this point, it can be concluded that the UV-vis differential spectra suggest a strong change in the electrode coverage at $\mathrm{E}<-0.58 \mathrm{~V}$ and, due to the difference between the adsorption/deposition and dissolution/desorption kinetics, the bands at 575 and $670 \mathrm{~nm}$ are more defined during the positive potential sweep.

\section{Gold (210)}

Lead upd on $\mathrm{Au}(210)$ presents three pairs of peaks (Fig. 5) in agreement with Ref. 8, but the reversibility is slightly different. Peaks are labeled as follows : $\mathrm{A} 1$ and $\mathrm{D} 1=-0.38$; $\mathrm{A} 2$ and $\mathrm{D} 2=-0.645$ and $\mathrm{A} 3$ and $\mathrm{D} 3=-0.795 \mathrm{~V} / \mathrm{MSE}$. The middle peaks A2 and D2 are smaller than the other two peaks. As pointed out by Hamelin and Lipkowski ${ }^{9}$, the 


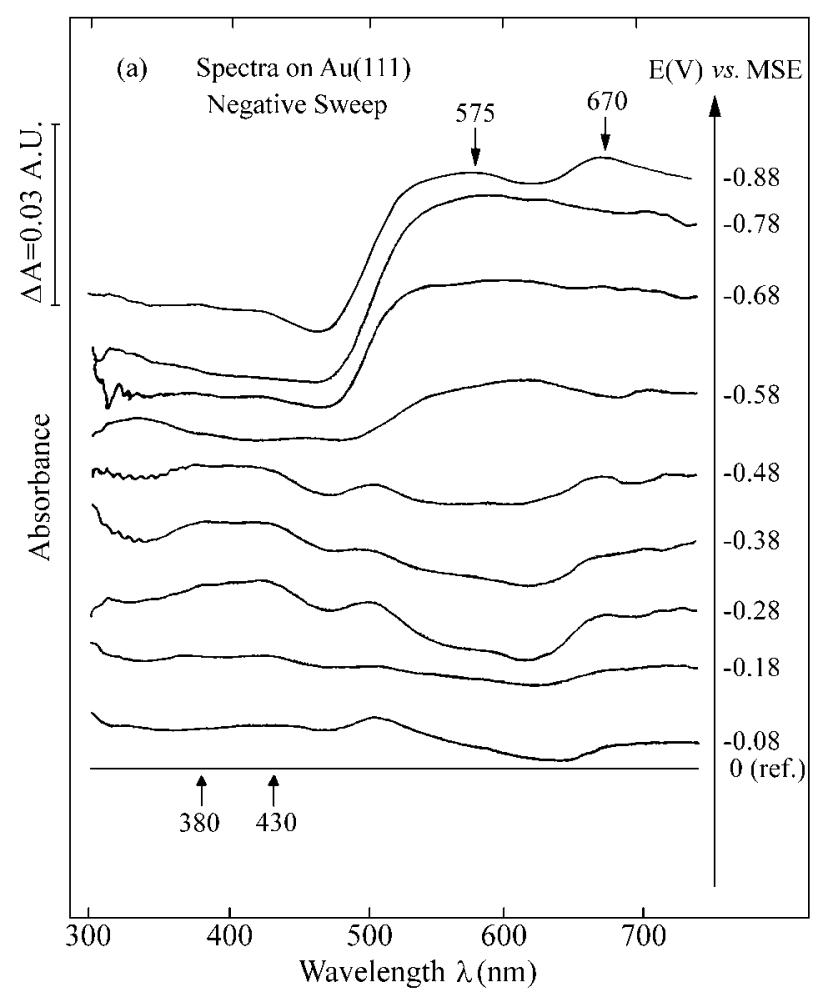

Figure 3a. Two-dimensional UV-visible differential reflectance spectra corresponding to the deposition of lead on $\mathrm{Au}(111)$ in $10 \mathrm{mM} \mathrm{HClO}_{4}+1$ $\mathrm{mM} \mathrm{Pb}(\mathrm{ClO} 4) 2$ solution during a negative potential sweep from 0 to -0.88 $\mathrm{V} / \mathrm{MSE}$, at $2 \mathrm{mV} \mathrm{s}^{-1}$, temperature $\approx 25^{\circ} \mathrm{C}$ (reference spectrum taken at $0 \mathrm{~V} / \mathrm{MSE})$

number, the amplitude, and the width of the peaks in the cyclic voltammograms are related to the atomic arrangement of the crystallographic face of the metal substrate. Additionally, it was shown in LEED experiments ${ }^{9}$ that the different intensities of the peaks are associated with discrete changes in the structure of the lead deposit. In the specific case of the face (210), which is a turning point of the (110)-(100) zone, the changes of the structure related to the current peaks in the CV seem to be closer to those corresponding to the (110) face 9 .

Figure 6 shows UV-vis differential spectra for the $\mathrm{Au}(210) / \mathrm{Pb}$ system at the potentials of the deposition peaks. It is possible to distinguish three types of spectra corresponding to the three pairs of peaks (A1/D1, A2/D2, and A3/D3). For peaks A1/D1, at -0.38 V/MSE, the spectrum presents two main bands at 575 and $660 \mathrm{~nm}$. These two bands shift to 520 and $605 \mathrm{~nm}$ for peaks A2/D2, at $-0.645 \mathrm{~V} / \mathrm{MSE}$. Then, the width and the amplitude of the absorption bands increase considerably for the peaks $\mathrm{A} 3 / \mathrm{D} 3$, as for the $\mathrm{Au}(111) / \mathrm{Pb}$ system. Such an increase in the amplitude of the bands can be interpreted in the same way as for the previous system.

The spectra in Figs. $7 \mathrm{a}$ and $7 \mathrm{~b}$ were obtained during a $\mathrm{CV}$ at $2 \mathrm{mV} \mathrm{s}^{-1}$ for the deposition and dissolution of lead,

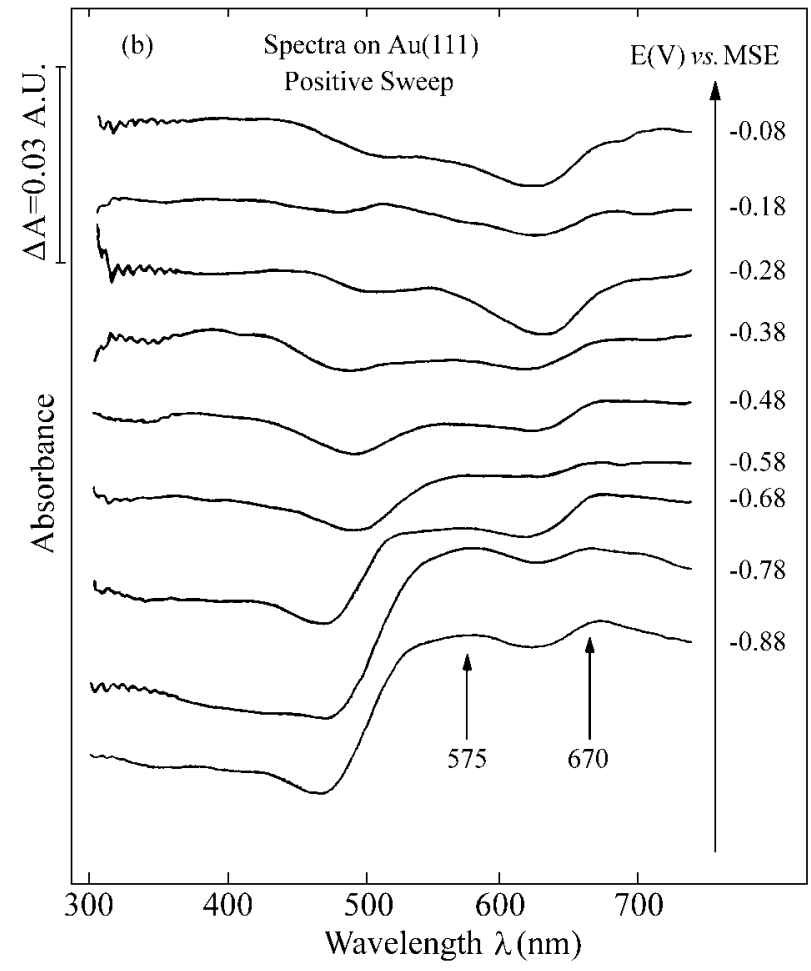

Figure 3b. Two-dimensional UV-visible differential reflectance spectra corresponding to the dissolution of lead on $\mathrm{Au}(111)$ in $10 \mathrm{mM} \mathrm{HClO}_{4}+$ $1 \mathrm{mM} \mathrm{Pb}\left(\mathrm{ClO}_{4}\right)_{2}$ solution during a positive potential sweep from -0.88 to $0 \mathrm{~V} / \mathrm{MSE}$, at $2 \mathrm{mV} \mathrm{s}^{-1}$, temperature $\approx 25^{\circ} \mathrm{C}$ (reference spectrum taken at $0 \mathrm{~V} / \mathrm{MSE})$.

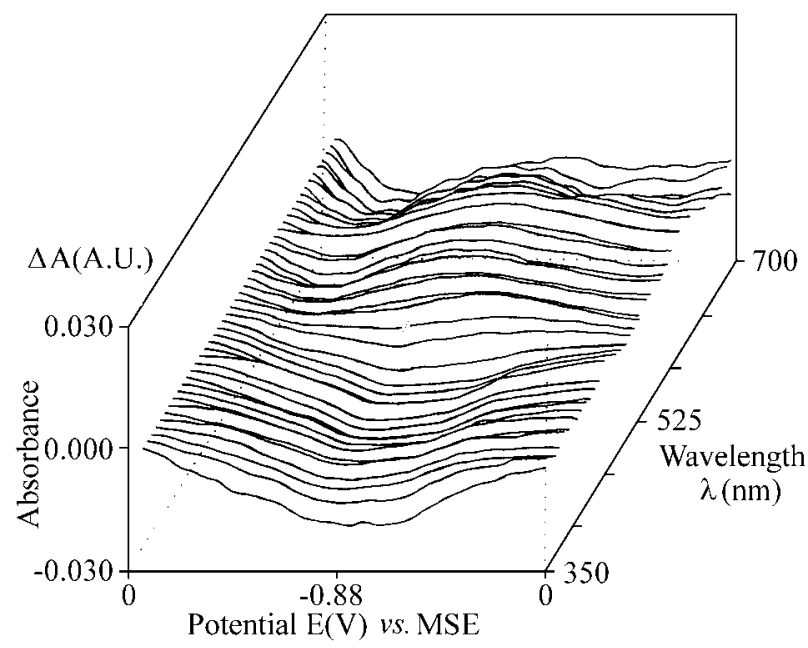

Figure 4. Three-dimensional diagrams obtained from Figs. 3a and $3 b$ during the upd of lead on $\mathrm{Au}(111)$ in $10 \mathrm{mM} \mathrm{HClO}_{4}+1 \mathrm{mM} \mathrm{Pb}\left(\mathrm{ClO}_{4}\right)_{2}$ solution in the potential range from -0.88 to $0 \mathrm{~V} / \mathrm{MSE}$, temperature $\approx 25^{\circ} \mathrm{C}$ (reference spectrum taken at $0 \mathrm{~V} / \mathrm{MSE}$ ).

respectively. The bands appearing at $\lambda>475 \mathrm{~nm}$ for the $\mathrm{Au}(210) / \mathrm{Pb}$ system are somewhat narrower than those for the $\mathrm{Au}(111) / \mathrm{Pb}$ system shown in Figs. 3a and $3 \mathrm{~b}$. As observed before for $\mathrm{Au}(111)$, the spectra in Fig. 7b, corre- 
sponding to the positive potential sweep, present a better definition of the bands at 520 and $600 \mathrm{~nm}$ between -0.88

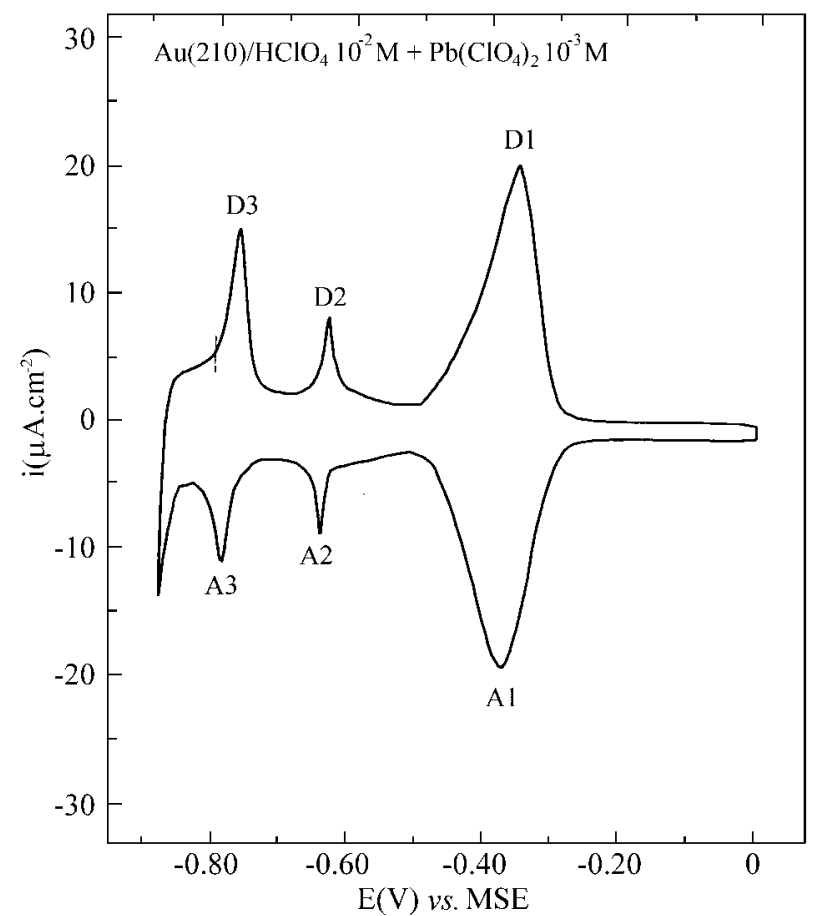

Figure 5. Cyclic voltammogram of $\mathrm{Au}(210)$ in $10 \mathrm{mM} \mathrm{HClO} 4+1 \mathrm{mM}$ $\mathrm{Pb}\left(\mathrm{ClO}_{4}\right)_{2}$ at $10 \mathrm{mV} \mathrm{s}^{-1}$ in the potential range from 0 to $-0.88 \mathrm{~V} v s$. MSE, temperature $\approx 25^{\circ} \mathrm{C}$.

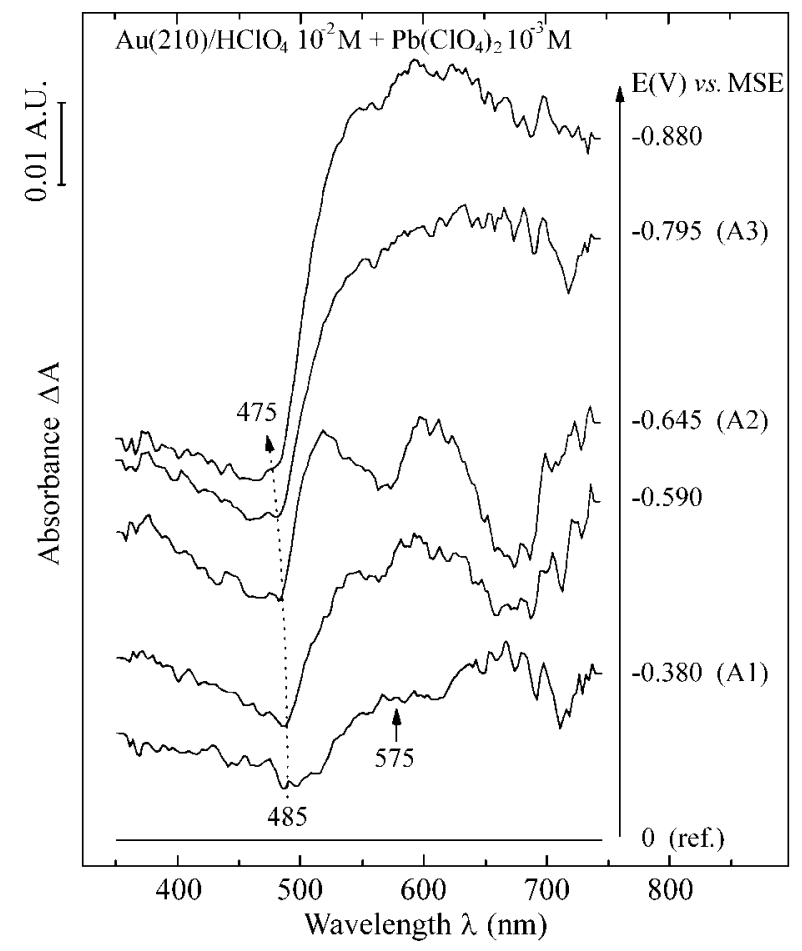

Figure 6. UV-visible differential reflectance spectra of $\mathrm{Au}(210) / 10 \mathrm{mM}$ $\mathrm{HClO}_{4}+1 \mathrm{mM} \mathrm{Pb}\left(\mathrm{ClO}_{4}\right)_{2}$ at the fixed potentials shown (reference spectrum taken at $0 \mathrm{~V} / \mathrm{MSE})$. and $-0.38 \mathrm{~V}$ than in the negative potential sweep (Fig. 7a). This observation confirms that there are differences be-

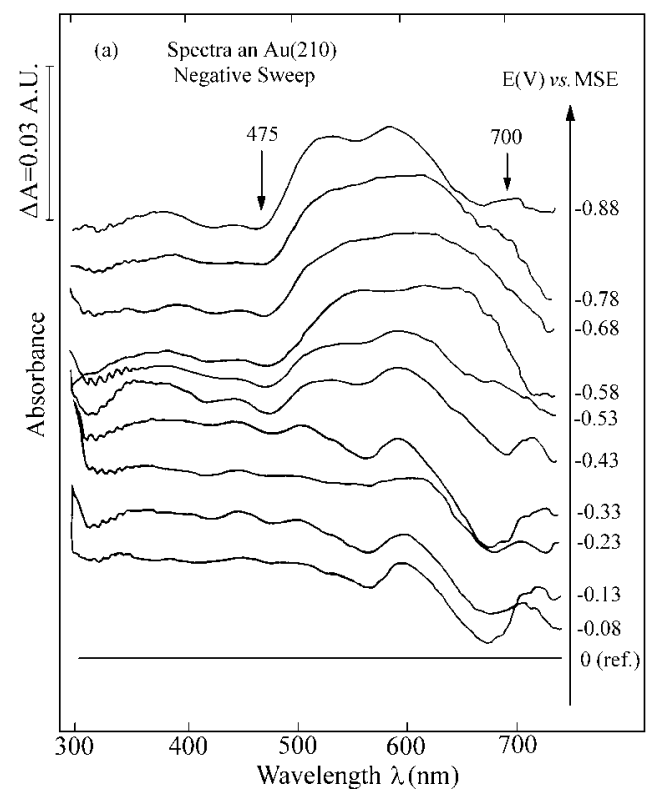

Figure 7a. Two-dimensional UV-visible differential reflectance spectra corresponding to the deposition of lead on $\mathrm{Au}(210)$ in $10 \mathrm{mM} \mathrm{HClO} 4+$ $1 \mathrm{mM} \mathrm{Pb}\left(\mathrm{ClO}_{4}\right)_{2}$ solution during the negative potential scan between 0 and $-0.88 \mathrm{~V} / \mathrm{MSE}$, at $2 \mathrm{mV} \mathrm{s}^{-1}$, temperature $\approx 25^{\circ} \mathrm{C}$ (reference spectrum taken at $0 \mathrm{~V} / \mathrm{MSE})$.

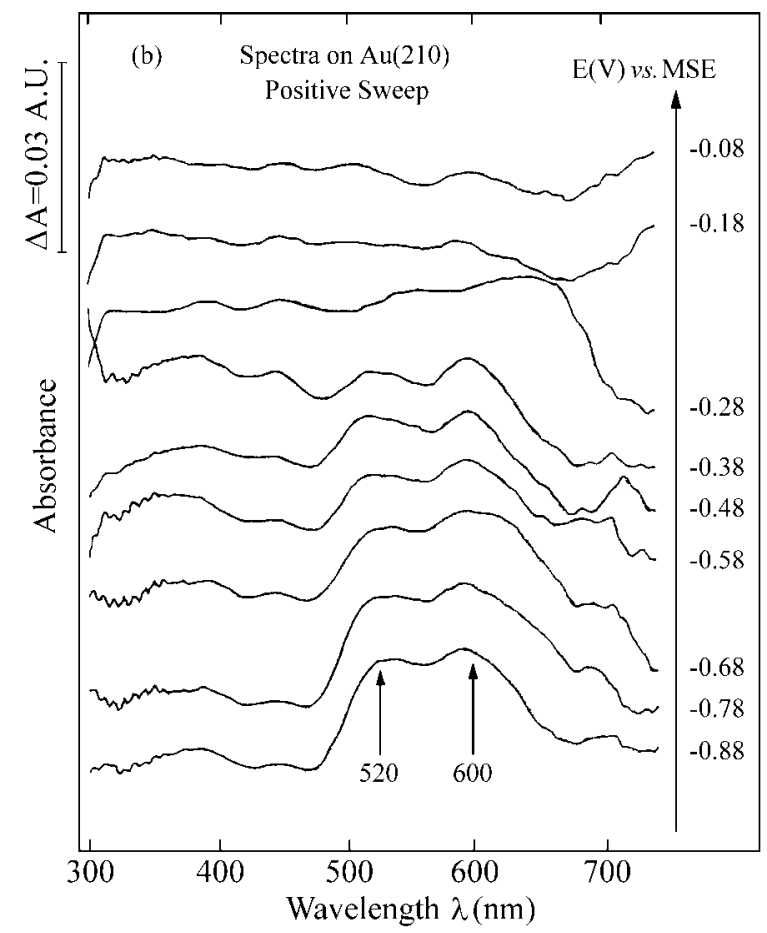

Figure 7b. Two-dimensional UV-visible differential reflectance spectra corresponding to the dissolution of lead on $\mathrm{Au}(210)$ in $10 \mathrm{mM} \mathrm{HClO}_{4}+$ $1 \mathrm{mM} \mathrm{Pb}\left(\mathrm{ClO}_{4}\right)_{2}$ solution during the positive potential scan between -0.88 and $0 \mathrm{~V} / \mathrm{MSE}$, at $2 \mathrm{mV} \mathrm{s}^{-1}$, temperature $\approx 25^{\circ} \mathrm{C}$ (reference spectrum taken at $0 \mathrm{~V} / \mathrm{MSE}$ ). 


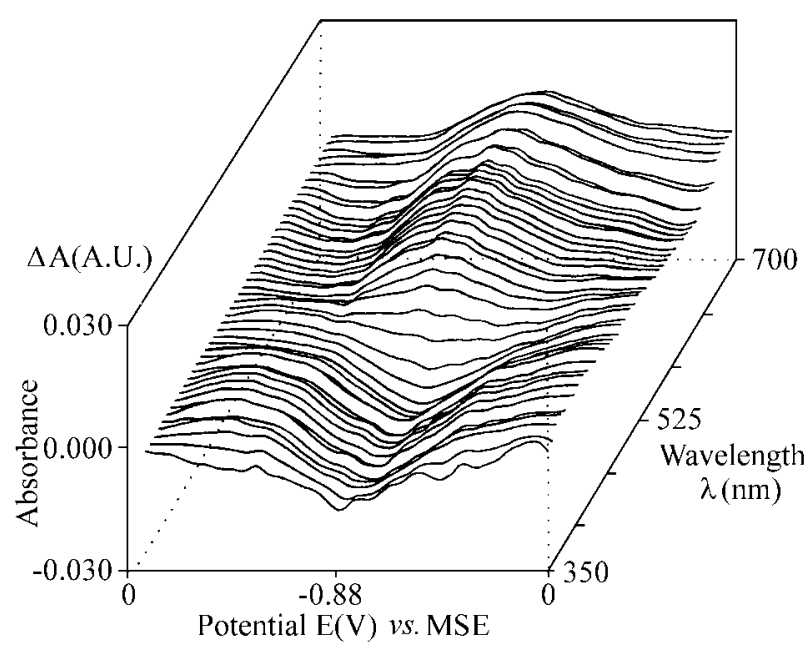

Figure 8. Three-dimensional diagrams obtained from Figs. 7a and $7 \mathrm{~b}$ during the upd of lead on $\mathrm{Au}(210)$ in $10 \mathrm{mM} \mathrm{HClO}_{4}+1 \mathrm{mM} \mathrm{Pb}\left(\mathrm{ClO}_{4}\right)_{2}$ solution in the potential range from -0.88 to $0 \mathrm{~V} / \mathrm{MSE}, 25^{\circ} \mathrm{C}$ (reference spectrum taken at $0 \mathrm{~V} / \mathrm{MSE}$ ).

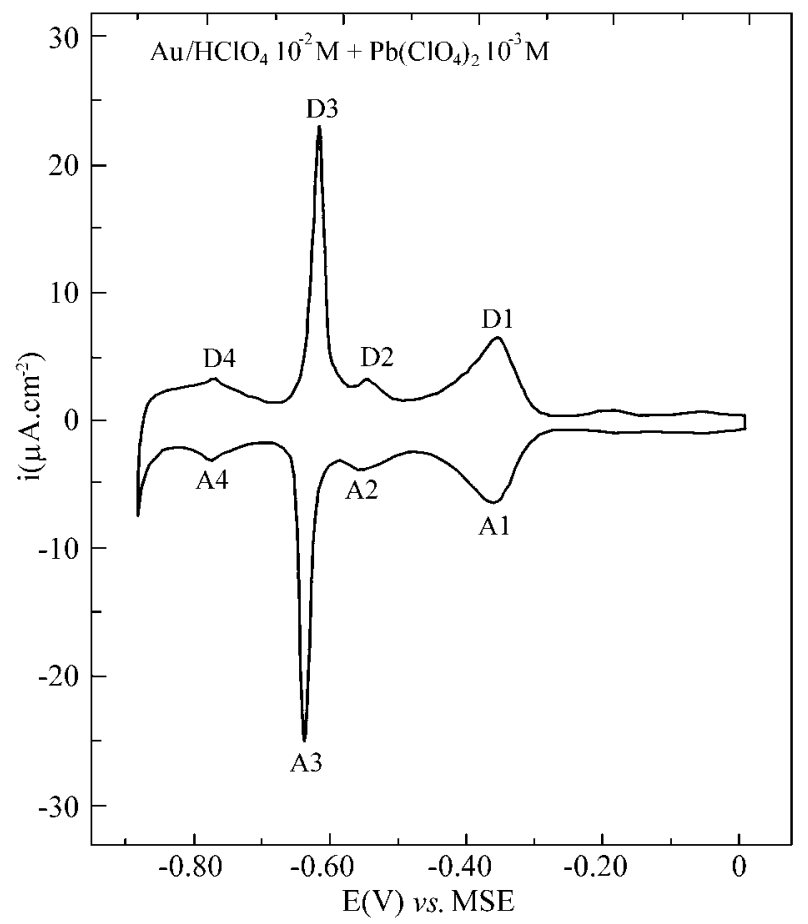

Figure 9. Cyclic voltammogram of a polycrystalline gold electrode in $10 \mathrm{mM} \mathrm{HClO}_{4}+1 \mathrm{mM} \mathrm{Pb}\left(\mathrm{ClO}_{4}\right)_{2}$ recorded at $10 \mathrm{mV} \mathrm{s}^{-1}$ in the potential range from 0 to $-0.88 \mathrm{~V}$ vs. MSE, temperature $\approx 25^{\circ} \mathrm{C}$.

tween the processes of deposition and dissolution of lead which can be related to intrinsic changes of the structure of the deposit and/or changes in the kinetic parameters. As it can be seen in the 3D spectra presented in Fig. 8, for the (210) face the spectra have the same general features of the (111) face. However, the relative changes in absorbance with potential are more pronounced for the (210) face, as can be observed from a comparison of Figs. 8 and 4. The

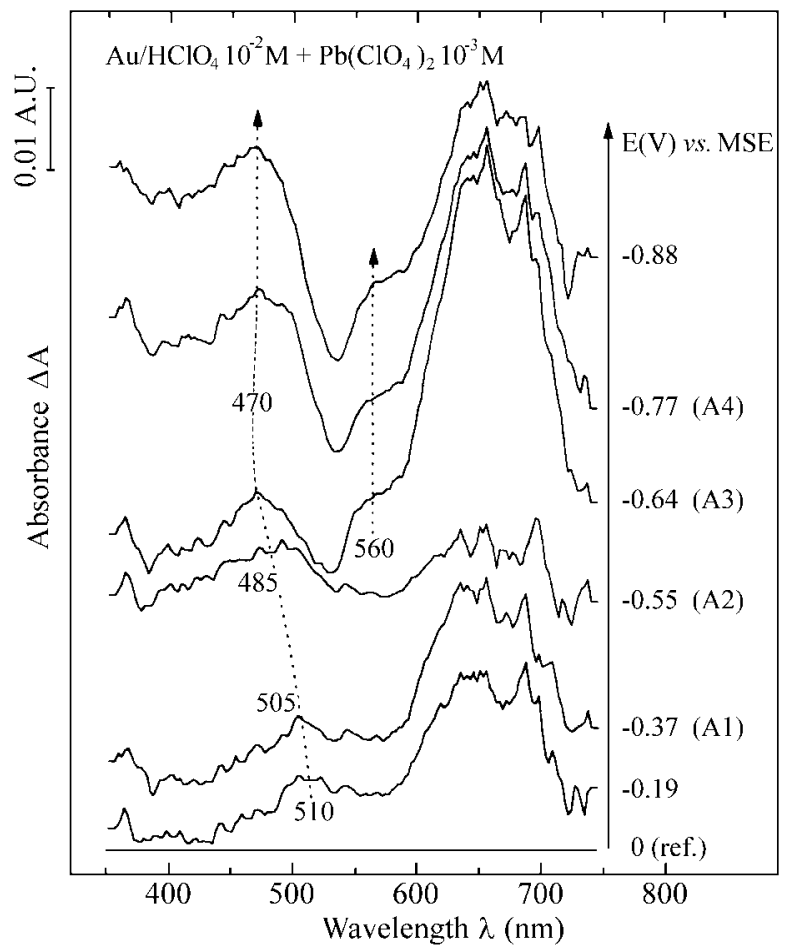

Figure 10. UV-visible differential reflectance spectra of polycrystalline $\mathrm{Au} / 10 \mathrm{mM} \mathrm{HClO} 4+1 \mathrm{mM} \mathrm{Pb}\left(\mathrm{ClO}_{4}\right)_{2}$ at the fixed potentials shown (reference spectrum taken at $0 \mathrm{~V} / \mathrm{MSE}$ ).

deposition-dissolution process is not wholly reversible as far as the spectra are concerned, since, as mentioned for $\mathrm{Au}(111)$, the last spectrum in Fig. 8 is not a horizontal line of zero absorbance.

\section{Polycrystalline gold}

The cyclic voltammogram at $10 \mathrm{mV} \mathrm{s}^{-1}$ for polycrystalline gold in an acidic solution containing lead, in the potential range from 0 to $-0.88 \mathrm{~V} / \mathrm{MSE}$, shows four pairs of peaks (Fig. 9). All processes are rapid, except that corresponding to the pair of sharp peaks A3 and D3, which has a peak separation of about $20 \mathrm{mV}$. This behavior is quite similar to that observed before ${ }^{5}$, but for a slight difference in the intensity of the peaks, probably due to the difference in solution composition. According to Engelsmann et al. ${ }^{5}$, the behavior of a polycrystalline gold substrate for lead upd is almost the same as that of $\mathrm{Au}(110)$. Then, the present results can be interpreted on the basis of the assumptions made by Hamelin and Lipkowski on cyclic voltammetric results and LEED results ${ }^{9}$. For instance, peak A1 at -0.37 V/MSE was attributed to a $\mathrm{p}(1 \mathrm{x} 1)$ structure and peak $\mathrm{A} 4$ at -0.77 V/MSE to a $\mathrm{p}(4 \mathrm{x} 4)$ structure. Peaks A3 at -0.64 V/MSE and D3 at -0.62 V/MSE were attributed to a transformation of the structure of the lead submonolayer, perhaps due to the presence of (111) facets present in the surface. The intensity and potential of peaks A3-D3 coincide with those of peaks A5 and D5 for $\mathrm{Au}(111)^{5,9}$ (Fig. 1), 
which reinforces the last assumption. Thus, it can be proposed that the structure of lead on the polycrystalline gold surface could present a $\mathrm{p}(\sqrt{28} \times \sqrt{28}) 18^{\circ} 90^{\prime}$ geometry, or one very close to it, before it changes to a $\mathrm{p}(4 \mathrm{x} 4)$ structure.

Figure 10 shows the UV-vis differential spectra at the potentials of the peaks observed in Fig. 9. The spectrum at $0 \mathrm{~V} / \mathrm{MSE}$ was also used as reference. A small band shifts from 510 to $470 \mathrm{~nm}$ with decreasing potential. For $\lambda>510$ $\mathrm{nm}$ the spectra are basically the same, but for the shoulder at $560 \mathrm{~nm}$ at potentials more negative than $-0.64 \mathrm{~V}$. Additionally, there is a large increase of absorbance at $\mathrm{E}=-0.64$ $\mathrm{V}$ (peak A3).

\section{Discussion}

Two points are worth discussing. The first one concerns the interpretation of the behavior of polycrystalline gold in the light of the results obtained with single crystal faces. In other words, the question is whether, optically, the polycrystal behaves as a weighted contribution of elementary crystallites of definite orientation. The second point concerns the adsorption states of the lead adatoms on the gold surface. It is important to understand if the optical response in the UV-visible range provides information on the type of substrate sites which are occupied by $\mathrm{Pb}$ adatoms and if there is a structural dependence of the upd process.

Optical behavior of lead adatoms on polycrystalline gold as compared to single crystals

A comparison of the spectra for the deposition of lead on polycrystalline gold (Fig. 10) with those for $\mathrm{Au}(111)$ (Fig. 2) and $\mathrm{Au}(210)$ (Fig. 6), shows that a lead submonolayer on single crystal faces absorbs over a much wider wavelength range (roughly from 480 to $720 \mathrm{~nm}$ ) than on the polycrystal electrode (600 to $720 \mathrm{~nm}$ ). Conversely, the intensity of the bands is about $40 \%$ greater on the polycrystal $\left(\triangle \mathrm{A}_{\max }\right.$ of about $0.047 \mathrm{~A} . \mathrm{U}$. at peak $\left.\mathrm{A} 3\right)$ than on single crystals, where $\Delta \mathrm{A}_{\max }$ is only 0.033 and $0.030 \mathrm{~A}$.U. on the (111) and (210) planes, at peaks A5 and A3, respectively.

However, looking carefully at Fig. 10 (polycrystal) and Fig. 2 (the (111) plane) it is interesting to note that in the negative potential sweep negative bands, corresponding to an increase of reflectance, are seen at around $530 \mathrm{~nm}$ in the former and $510 \mathrm{~nm}$ in the latter. No similar bands are seen with $\mathrm{Au}(210)$. Interestingly, peak A3 for the polycrystal and peak $\mathrm{A} 5$ for $\mathrm{Au}(111)$ occur at about the same potential, $-0.65 \mathrm{~V}$. As noted above, it is at these peaks that the reconstruction of the lead submonolayer is supposed to occur, leading to a change from a $\mathrm{p}(\sqrt{3} \times \sqrt{3}) 30^{\circ}$ to a $\mathrm{p}(\sqrt{28} \times \sqrt{28}) 18^{\circ} 90^{\prime}$ pattern ${ }^{9}$. At the same time the surface coverage increases dramatically, so that it becomes clear that the negative peaks of the UVDRS spectra result from a decrease of the number of free gold sites (i.e., not covered by lead) near $-0.60 \mathrm{~V} / \mathrm{MSE}$ and consequently a decrease of the well-known absorption edge at $c a .500 \mathrm{~nm}$ of metallic gold $^{1}$. As expected, nothing similar is seen with the (210) face.

\section{The adsorption states of $\mathrm{Pb}$ adatoms on $\mathrm{Au}$}

The spectrum chosen as reference corresponds to a well defined electrochemical state of the interface with no upd lead adatoms, which allows us to determine the formation or the disappearance of structures at the electrochemical interface.

The shapes of the UV-vis differential spectra during the upd of $\mathrm{Pb}$ on $\mathrm{Au}$ are similar and prove clearly the existence of at least two states of $\mathrm{Pb}$ on the substrate (Figs. 2, 6 and $10)$, namely, the submonolayer of $\mathrm{Au}-\mathrm{Pb}_{\text {ads }}$ and the complete layer of $\mathrm{Pb}_{\mathrm{ads}}$ which corresponds to the final structure $-\mathrm{Pb}_{\text {ads }}-\mathrm{Pb}_{\text {ads }}$.

At potentials higher than $-0.35 \mathrm{~V} / \mathrm{MSE}$ the differential spectra practically show no bands. Submonolayers of $\mathrm{Pb}_{\text {ads }}$ species predominate for polycrystalline gold between -0.19 and $-0.55 \mathrm{~V} / \mathrm{MSE}$, for $\mathrm{Au}(111)$ between -0.36 and -0.59 V/MSE and for $\mathrm{Au}(210)$ between -0.38 and $-0.64 \mathrm{~V} / \mathrm{MSE}$. The spectra of $\mathrm{Au}(111)$ and $\mathrm{Au}(210)$ (Figs. 2 and 6) show little absorption below $470 \mathrm{~nm}$ and a progressive increase of absorbance at wavelengths above $500 \mathrm{~nm}$. An increase of the absorbance at lower potentials is likely to correspond to a restructuring and a redistribution of the $\mathrm{Pb}_{\text {ads }}$ atoms on the gold surface, forming multiple bonds between the $\mathrm{Pb}_{\mathrm{ads}}$ species like on a metallic surface. This adsorbed state is more defined for single crystals like $\mathrm{Au}(111)$ and $\mathrm{Au}(210)$. The very sharp (i-E) peaks, according to the Frumkin isotherm model, denote strong lateral interactions between adsorbates, i.e., of -( $\left.\mathrm{Pb}_{\mathrm{ads}}-\mathrm{Pb}_{\mathrm{ads}}\right)$ - type.

Finally, the UV-vis spectra (Figs. 3 and 7) show a fair reversibility of the reconstruction process of the lead layer on gold between -0.88 and $-0.58 \mathrm{~V} / \mathrm{MSE}$.

\section{Conclusions}

This UVDRS study of the $\mathrm{Au} / \mathrm{Pb}$ interface completes and confirms some assumptions obtained from CVs about the occurrence of different adsorption states of lead on a gold surface and the dependence of the surface coverage on the electrode potential. In particular, it can be deduced from the UV-vis spectra that the changes of surface coverage by an adsorbed species lead to large changes of the amplitude of absorption bands.

By comparing the spectra obtained with the two $\mathrm{Au}$ single crystal faces studied here with those of the gold polycrystal, it becomes clear that the reconstruction processes affecting the lead submonolayer are very similar for the polycrystal and for the (111) face.

All the results obtained here demonstrate the high sensitivity of the UVDRS technique for detecting small changes of reflectivity due to the presence of an adsorbed layer, even at low coverage. 


\section{Acknowledgments}

The authors thank Dr. A. Hamelin from LEI / CNRS for preparing the gold single crystals. This work was supported by a bilateral exchange program between CNPq (Brazil) and CNRS (France).

\section{References}

1. Kolb, D.M. In Advances in Electrochemistry and Electrochemical Engineering, vol. 11, Gerischer, H.; Tobias, C.W., eds.; Wiley, New York, 1978.

2. Adzic, R.R.; Yeager, E.; Cahan, B.D. J. Electrochem. Soc. 1974, 21, 474.

3. Schultze, J.W.; Dickertmann, D. Surf. Sci. 1976, 54, 489.

4. Hamelin, A. J. Electroanal. Chem. 1979, 101, 285.

5. Engelsmann, K.; Lorenz, W.J.; Schmidt, E. J. Electroanal. Chem. 1980, 114, 1.
6. Engelsmann, K.; Lorenz, W.J.; Schmidt, E. J. Electroanal. Chem. 1980, 114, 11.

7. Hamelin, A.; Katayama, A. J. Electroanal. Chem. 1981, 117, 221.

8. Hamelin, A. J. Electroanal. Chem., 1984, 165, 167.

9. Hamelin, A.; Lipkowski, J. J. Electroanal. Chem. 1984, 171, 317.

10. Rakotondrainibe, A.; Spinelli, A.; Lamy, C.; Beden, B. Spectroscopy Europe 1993, 5, 20.

11. Collas, N.; Beden, B.; Léger, J-M.; Lamy, C. J. Electroanal. Chem. 1985, 186, 287.

12. Kolb, D.M. In Spectroelectrochemistry, Theory and Practice, Gale, R.J., ed.; Plenum Press, New York, 1988.

13. Hamelin, A. In Modern Aspects of Electrochemistry, Vol. 16, Conway, B.E.; Bockris, J.O’M.; White, R., eds.; chapter 1, p. 1, Plenum Press, New York, 1985.

14. Hahn, F.; Beden, B.; Croissant, M.J.; Lamy, C. Electrochim. Acta 1986, 31, 335.

FAPESP helped in meeting the publication costs of this article 